\title{
Frequency of coronary artery stenosis in patients with asymptomatic familial hypercholesterolemia and its association with carotid intimal thickness and cardio-ankle vascular index [Corrigendum]
}

\begin{abstract}
Suzuki M, Takahashi M, Iizuka T et al. Frequency of coronary artery stenosis in patients with asymptomatic familial hypercholesterolemia and its association with carotid intimal thickness and cardio-ankle vascular index. Research Reports in Clinical Cardiology. 2016;7:83-90.
\end{abstract}

On page 83, in the Abstract, Results heading: "The proportion of male patients and mean low-density lipoprotein-cholesterol level were higher in patients with CAS than in those without CAS $(P<0.05)$." should be "The proportion of male patients and mean low-density lipoprotein-cholesterol level were higher in patients with CAS than in those without CAS."

On page 83, in the Abstract, Conclusion heading: "CAS was identified in $>22.6 \%$ of the asymptomatic FH patients" should be "CAS was identified in $22.6 \%$ of the asymptomatic FH patients"

On page 86, right column, the last sentence: “...CAS were $0.82 \mathrm{~mm}$ and $5.1 \mathrm{~mm}$, respectively." should be "...CAS were $0.82 \mathrm{~mm}$ and 5.1, respectively."
Research Reports in Clinical Cardiology

\section{Publish your work in this journal}

Research Reports in Clinical Cardiology is an international, peerreviewed, open access journal publishing original research, reports, editorials, reviews and commentaries on all areas of cardiology in the clinic and laboratory. The manuscript management system is completely online and includes a very quick and fair peer-review system.

\section{Dovepress}

Visit http://www.dovepress.com/testimonials.php to read real quotes from published authors. submit your manuscript

Dovepress

f

in $\square$ 